\title{
Is It Possible to Shift from Down to Top Rank? A Focus on the Mesolimbic Dopaminergic System and Cocaine Abuse
}

\author{
Inês M. Amaral *(D), Alex Hofer and Rana El Rawas \\ Division of Psychiatry I, Department of Psychiatry, Psychotherapy and Psychosomatics, \\ Medical University Innsbruck, 6020 Innsbruck, Austria; a.hofer@i-med.ac.at (A.H.); \\ rana.el-rawas@i-med.ac.at (R.E.R.) \\ * Correspondence: ines.amaral@i-med.ac.at; Tel.: +43-512-504-23710
}

Citation: Amaral, I.M.; Hofer, A.; El Rawas, R. Is It Possible to Shift from Down to Top Rank? A Focus on the Mesolimbic Dopaminergic System and Cocaine Abuse. Biomedicines 2021, 9, 877. https://doi.org/10.3390/ biomedicines 9080877

Academic Editors: Estela Castilla Ortega and Antonia Serrano

Received: 14 June 2021

Accepted: 20 July 2021

Published: 23 July 2021

Publisher's Note: MDPI stays neutral with regard to jurisdictional claims in published maps and institutional affiliations.

Copyright: (c) 2021 by the authors. Licensee MDPI, Basel, Switzerland. This article is an open access article distributed under the terms and conditions of the Creative Commons Attribution (CC BY) license (https:// creativecommons.org/licenses/by/ $4.0 /)$.
Abstract: Impaired social behavior is a common feature of many psychiatric disorders, in particular with substance abuse disorders. Switching the preference of the substance-dependent individual toward social interaction activities remains one of the major challenges in drug dependence therapy. However, social interactions yield to the emergence of social ranking. In this review, we provide an overview of the studies that examined how social status can influence the dopaminergic mesolimbic system and how drug-seeking behavior is affected. Generally, social dominance is associated with an increase in dopamine $\mathrm{D}_{2 / 3}$ receptor binding in the striatum and a reduced behavioral response to drugs of abuse. However, it is not clear whether higher $D_{2}$ receptor availability is a result of increased $\mathrm{D}_{2}$ receptor density and/or reduced dopamine release in the striatum. Here, we discuss the possibility of a potential shift from down to top rank via manipulation of the mesolimbic system. Identifying the neurobiology underlying a potential rank switch to a resilient phenotype is of particular interest in order to promote a positive coping behavior toward long-term abstinence from drugs of abuse and a protection against relapse to drugs. Such a shift may contribute to a more successful therapeutic approach to cocaine addiction.

Keywords: drugs of abuse; social interaction; social rank; mesolimbic system; dopamine; social reorganization; animal models; resilience; vulnerability; relapse

\section{Introduction}

Impaired social behavior is a common feature of many psychiatric disorders including substance abuse disorders, depression, schizophrenia and autism. In the context of substance use disorders, disturbances in social interaction are associated with an increased drug consumption and challenge treatment success in recovering addicts [1]. Therefore, switching the behavior of the substance-dependent individual toward social interaction activities remains one of the major challenges in drug dependence therapy [2].

However, social interaction between at least two individuals, usually of the same species, yields to the emergence of social ranking in the group. A group is defined as a set of conspecific individuals that remain together and interact with each other more than with other conspecifics [3]. Social rank in a group of individuals constantly monitors one's standing in relation to others and uses that information to guide behavior [4], such as access to resources and defending territories. Therefore, hierarchical rank has broad effects on physical and mental health due to the risk factors associated with living in a particular rank [5].

How does social rank impact drug taking? How is it believed to be mediated? These questions have been addressed by several research groups (see reviews [6-9]). However, the conclusions did not emerge in the same direction. In this review, we will overview these studies and address the possibility of switching the profile of a susceptible subordinate individual into a resilient dominant one. 


\section{Social Rank and Drugs of Abuse}

Studies in humans [10] and animals [11-13] demonstrate that social status is an important determinant of drug taking. Vulnerability to psychostimulants appears to be a feature of socially subordinate and socially stressed animals [14,15]. Indeed, social defeat stress in rats enhanced the acquisition of cocaine self-administration and increased the motivation to seek and take a drug [11,16]. Social defeat is experimentally initiated when a male rodent is introduced into the home cage of an older, aggressive, dominant male [17], triggering depression-like behaviors [18].

Consistent with these findings, socially subordinate male cynomolgus monkeys have been shown to self-administer more total cocaine [13] and to be more sensitive to the relative reinforcing strength of cocaine than dominant monkeys [19]. However, in male rats, social dominance was found to be associated with higher rates of intravenous cocaine self-administration [14]. Next to obvious species differences, the discrepancy in the method used to assess social dominance between non-human primates and rats in the latter study could explain the diverging results [14]. Indeed, in non-human primates, social dominance was identified to be based mainly on aggressive dyadic encounters, while in rats the social rank was assessed based on resource competition for a highly palatable liquid.

Identification of social rank is also possible through the performance of a tube test, based on confrontations within a plastic tube between each possible pairs of a group. A mouse that forces a conspecific out of its way is designated as the 'winner', or the dominant. The one that retreats backwards from the tube first is designated as the 'loser' or the subordinate [20]. In a study by [21], the submissive mice from four genetically identical male mice, determined by a tube test and the sharing of beneficial resources, had a significantly higher locomotor sensitization in response to repeated injections of cocaine in comparison to the dominant mice. This difference was maintained on the challenge day, thereby suggesting that dominant mice have a weaker behavioral response to cocaine.

In line with the previous studies linking social dominance with resilience to drugs of abuse, it was shown that stress-vulnerable submissive mice exposed to chronic mild stress displayed increased cocaine conditioned place preference (CPP), whereas stress-resilient dominant mice did not differ in preference from their non-stressed state [22]. These results suggest that social submission is associated with vulnerability to stress-induced increases of cocaine preference.

In rodents, social interaction was found to be rewarding [23]. When available as an alternative to drugs, dyadic social interaction reduced cocaine preference [24-28] (Figure 1) and prevented cocaine-induced reinstatement of cocaine preference [24]. Interestingly, the dyadic social interaction episodes did not result in the development of an observable hierarchy or a dominance/subordination rank $[29,30]$. Social hierarchy was determined from the observation of video recordings of the last social interaction conditioning session for signs of dominance/subordination between the pairs. A scoring system was used: h3 hierarchy score for aggressive dominance, defined as three consecutive attacks, such as aggressive grooming, biting, and chasing, by one mouse toward the other; h2 hierarchy score or passive dominance, defined as consistent threatening displacement by one mouse toward the other; $\mathrm{h} 1$ hierarchy score, defined as equal status between the pair; and h0 hierarchy score for subordinate behavior, defined as a retreat or withdrawal by one mouse as a reaction to the aggressiveness of the social partner [29]. In the vast majority of social pairs analyzed (i.e., 49 of the total 52 pairs), no visible signs of hierarchy emerged after four episodes of dyadic social interaction (hierarchy score h1) $[29,30]$. The lack of hierarchical organization in this paradigm was not surprising. Indeed, it seems that just four $15 \mathrm{~min}$ episodes of dyadic social interaction with an age and weight-matched conspecific were not enough to induce the establishment of social rank. However, this form of social interaction reward, when available as an alternative to drug use, was suggested as an approach to contracting negative stress effects and increasing resilience to drug use [15]. 


\section{Social interaction available as an alternative to drugs of abuse}
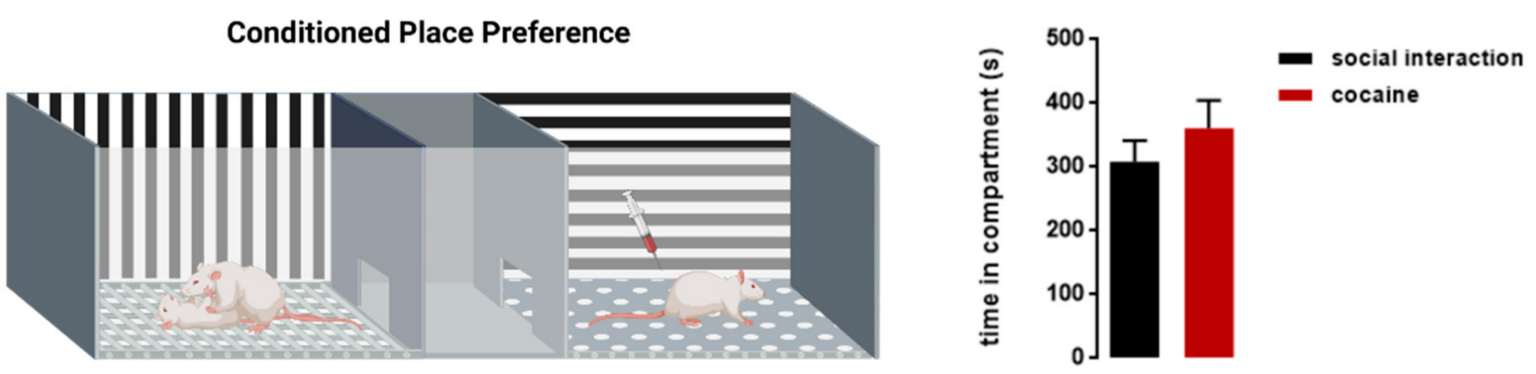

Figure 1. Social interaction as an alternative to drugs of abuse. A conditioned place preference (CPP) apparatus comprises a neutral central compartment connected to two chambers that are different in their context (vertical versus horizontal stripes on the walls) and texture (round versus square holes on the floor). During the conditioning phase, the animal is placed in one chamber of the CPP (in this example, the horizontal compartment) and receives a stimulus such as a cocaine intraperitoneal injection. The animal will then associate the effect of the stimulus with the corresponding context. In a concurrent CPP procedure, another stimulus, such as social interaction with an age and weight-matched conspecific, is made available in the alternative chamber (in this example, the vertical compartment) during the conditioning sessions. Thus, the animals are conditioned with cocaine in one compartment of the CPP and in the opposite compartment, they are conditioned with a social stimulus to incite social play behavior. That way, an animal will associate the context of the vertical compartment with the rewarding effects of social play. On the test day, when the doors to the stimulus-associated compartments are open and the animal is given the choice of where to spend more time, it will spend a similar amount of time in the cocaine-associated, and in the social interaction-associated, compartment. Social interaction reward and cocaine reward have an equal reward value $[25,26]$. Right panel: time rats subjected to a concurrent CPP protocol spent in each compartment during the test. $n=8$, Unpaired T-test, $\mathrm{t}(14)=0.9666, p=0.3501$ (n.s) [26].

These findings mostly correlate the state of social dominance, or even the state of equal hierarchy occurring in dyadic social interaction $[29,30]$ to a reduced behavioral response to abused drugs.

Notably, not only hierarchical relations (top-down or down-top), but also peer-to-peer relationships, or the so-called individual network, affect one's response to drugs of abuse. Compelling evidence demonstrates that peer pressure or social interaction in the same context as drugs can facilitate drug use among adolescents [15,31]. In rats, cocaine selfadministration is facilitated in socially housed rats if both animals of a pair have access to cocaine, whereas it is inhibited if only one member of the pair has access to cocaine [32]. Given that rats can behaviorally discriminate between drug-associated and non-drugassociated conspecifics [33], they express a social preference toward a partner with a shared history of drug exposure [34,35]. It appears that the rewarding effects of drugs and dyadic social interaction are enhanced when combined with each other [36-38]. However, we focus on dyadic social interaction available in an alternative context to drugs. This form of interaction with an age- and weight-matched conspecific was shown to consistently abolish the preference to drugs [24-26], thereby allowing effective coping to build resilience against drug abuse [15].

\section{Social Rank and the Mesolimbic Dopamine System}

The mesolimbic dopaminergic system was identified as the key component in reward assessment [39]. This system is comprised of dopaminergic (DA) neurons with cell bodies in the ventral tegmental area (VTA), which project to forebrain areas including limbic structures such as the nucleus accumbens (NAc), the amygdala and cortical areas including the prefrontal cortex (PFC). Natural rewards, as well as most substances that are abused by humans, including cocaine, increase extracellular concentrations of mesolimbic DA [40-42]. Stimulants such as cocaine increase synaptic dopaminergic concentrations by blocking the 
presynaptic dopamine transporter (DAT), thereby preventing DA re-uptake and increasing DA concentration in the synapse [43].

There are five DA receptors, designated D1 to D5. Based on their structural and pharmacological properties, a general subdivision into two groups has been made: the D1-like receptors, which stimulate intracellular cAMP levels, comprising D1 and D5, and the D2-like receptors, which inhibit intracellular cAMP levels, comprising D2, D3, and D4 receptors [44].

Mesolimbic dopaminergic transmission was suggested as a potential substrate for social ranking. Indeed, in a human study, a positive correlation was seen between dopamine $\mathrm{D}_{2 / 3}$ receptor binding potential in the striatum and social status [45]. Furthermore, using positron emission tomography (PET) imaging to study brain dopaminergic function in individually and socially housed cynomolgus macaques, it was found that social housing increased the amount or availability of $\mathrm{DA} \mathrm{D}_{2}$ receptors in the basal ganglia of dominant monkeys, and produced no change in subordinate monkeys [13].

In line with these findings, $\mathrm{D}_{2 / 3}$ receptor binding in the NAc shell and dorsal striatum of dominant rats was increased when compared to subordinate rats, and was accompanied by reduced DA levels in the NAc shell [14]. Interestingly, lower concentrations of DA were also found in the NAc of animals living in an enriched environment when compared to individually housed ones [46] but not to group-housed animals [47,48]. Therefore, it seems that the alterations in the mesolimbic system between rats living in enriched versus isolated environments mirror the differences observed in dominant versus subordinate animals, respectively [6,49]. Enriched environments are commonly defined as "a combination of complex inanimate and social stimulation" that usually consists of larger housing cages in a social environment, with a running wheel and toys from different textures changed on a regular basis to facilitate sensory, cognitive and motor stimulation [50-52].

Generally, in male monkeys, high $\mathrm{D}_{2 / 3}$ receptors and low DAT availability should lead to less vulnerability to cocaine reinforcement [53]. Similar observations were reported in rodent studies demonstrating the influence of environmental enrichment on dopaminergic function $[6,7,54]$. In contrast, high $\mathrm{D}_{2 / 3}$ receptor availability and elevated DAT measures were found in the NAc shell of socially dominant rats that maintained higher rates of cocaine self-administration [14]. In subordinate female monkeys, lower $\mathrm{D}_{2 / 3}$ receptor availability as compared to the dominants $[53,55]$, and reduced DAT availability, were correlated to less vulnerability to cocaine reinforcement [53]. Despite all dominant animals sharing the same feature of increased $\mathrm{D}_{2 / 3}$ receptor binding in the striatum $[13,14,53]$, studies on dominant rats [14] and subordinate female monkeys [53] show a direct correlation between DAT levels in the striatum and cocaine reinforcement-relationship that seems plausible as DAT is the main target of cocaine $[54,56]$. However, mice lacking DAT still self-administer cocaine [57]. It is also possible that changes in $\mathrm{D}_{2 / 3}$ receptors alone may not be sufficient to alter sensitivity to cocaine reinforcement [53]. Indeed, it was shown that the $\mathrm{D}_{2}$ receptor is not necessary for cocaine self-administration, but reduced $\mathrm{D}_{2}$ receptor levels appear to be involved in the escalation of cocaine intake that contributes to the development of cocaine addiction [58]. Importantly, mice lacking $\mathrm{D}_{3}$ receptors displayed an increase in vulnerability to cocaine manifested as enhanced cocaine self-administration and enhanced motivation for cocaine-taking and cocaine-seeking behavior [59].

In the search for biological markers associated with addictive traits, low striatal $\mathrm{D}_{2 / 3}$ receptor availability was linked to high impulsivity [60-62] and was predictive of high rates of intravenous cocaine self-administration [60]. Likewise, high DAT expression was found to be associated with impulsive choice [63], characterized by a marked shift of demand from the large and delayed toward the small and soon reward [64]. Indeed, intra-NAc DAT overexpressing rats showed increased impulsivity [64].

Highly impulsive rhesus monkeys have been shown to occupy lower positions in the social dominance hierarchy [65]. Interestingly, it was reported that dominant monkeys showing high $\mathrm{D}_{2 / 3}$ receptor availability were slower to touch a novel object placed in the home cage, consistent with them being less reactive to novelty and less vulnerable 
to cocaine abuse than subordinates [66]. Lower $\mathrm{D}_{2 / 3}$ receptor availability subordinate monkeys had faster latencies and displayed higher reactivity to novelty [66], consistent with a potential impulsive behavior [67]. Therefore, a lower $\mathrm{D}_{2 / 3}$ receptor coupled to a high DAT expression should lead to more vulnerability to cocaine reinforcement.

Neuropharmacological approaches also proposed a role for DA signaling in social ranking. Indeed, the administration of the $\mathrm{D}_{2}$ receptors antagonist, sulpiride, has been shown to attenuate social dominance when the drug is given to high social class macaques and mice [68]. In addition, the highest ranked individuals exhibited a lower bursting activity of VTA DA neurons [21]. Importantly, differences in VTA dopaminergic neurons firing properties were observed as a reflection of individual behavioral differences when animals were gathered in large environments [69]. Remarkably, high $\mathrm{D}_{2}$ receptor availability in the striatum was associated with resilience against the development of addiction [70]. Moreover, high sensation seeking may be linked with increased dopaminergic transmission into the striatum, which is in agreement with reduced protection against addictive behavior that is characteristic of individuals with low $\mathrm{D}_{2 / 3}$ receptor binding potentials [71].

Nevertheless, other studies have suggested that the activation of the dopaminergic projections from the VTA to the NAc and subsequent DA release in the NAc transiently facilitates social dominance through activation of $\mathrm{D}_{1^{-}}$, but not $\mathrm{D}_{2}$, receptor-signaling [72]. The same group also reported that stimulation of mesolimbic dopaminergic neurons seems to promote dominant behavior [73]. Even though these results may appear to be in direct contrast to others that supported a decrease in DA content in the NAc of dominant individuals, they pointed out the importance of the mesolimbic system as a potential substrate for social ranking. Indeed, the roles of $\mathrm{D}_{1}$ receptor function in social hierarchy remains less clear. A human PET study has also reported that subjects with low $\mathrm{D}_{1}$ receptor availability in the limbic-striatal regions exhibit higher aggression and socially dominant personalities [74], suggesting that $D_{1}$ and $D_{2}$ receptors may have opposite functions for determining social hierarchy. Low $\mathrm{D}_{1}$ signaling is also known to be associated with aggression [75], which may assist in attaining higher social dominance, and consequently higher social class. Consistently, low $\mathrm{D}_{1}$ functions facilitated social dominance in rodents housed in social groups [76]. In non-human primate social groups, $\mathrm{D}_{1}$ facilitation of social dominance remains less clear [76].

Moreover, mitochondrial function in the NAc was reported to be crucial for social hierarchy establishment [77]. Indeed, subordinate rats exhibited reduced mitochondrial complex I and II proteins and respiratory capacity as well as decreased ATP and increased reactive oxygen species production in the NAc [77]. Whereas the micro-infusion of specific mitochondrial complex I or II inhibitors into the NAc reduced social rank, intra-NAc infusion of a brain energy metabolism enhancer prevented the development of a subordinate status [77]. In mice, the metabolic profile in the NAc appears to be associated to social status. Under basal conditions, the subordinate showed lower levels of energy-related metabolites compared to dominants [78]. These findings suggest that mitochondrial function in the NAc might be a potential biomarker for social status.

\section{Social Rank and Sociability}

Individual differences in social behavior emerged after mice with low genetic diversity were living continuously in large groups [69]. A number of studies have shown that dominant-ranked mice exhibited a higher sociability than their subordinates [5,21,79]. Importantly, differences in sociability between the highest and lowest ranked mice were reported to pre-exist as a trait before gathering the animals into tetrads [21]. These findings suggest that social dominance, or a high rank, may positively influence social motivation.

When a hierarchical social group was exposed to chronic social defeat stress, different results were found. Indeed, one study reported decreased social interactions in both high- and low-ranked mice [5], whereas a second study found that low-ranked mice were more likely to develop social aversion [21]. Based on the hypothesis that high-ranked mice would be the ones challenged by stress-exposure, it was found that dominant mice 
exhibited strong social avoidance, whereas subordinate mice were not affected [78]. The discrepancies in the findings may be attributed to the intensity of the chronic social defeat stress, the time taken in establishing the hierarchy, and the way the results were analyzed. Apparently, when a longer time of cohabitation was investigated (i.e., up to four months), low-ranked mice were more prone to develop social aversion after exposure to chronic stressful conditions [21].

\section{Effects of Environmental Factors on Social Rank}

Given that environmental factors are essential in the determination of the individual vulnerability to drugs of abuse [15], we sought to search for potential effects of the environment on social ranking.

During the formation of social hierarchies, ranks are not determined exclusively by intrinsic factors such as body size, weight, and individual traits, but rather by a range of interacting individual and environmental factors $[5,8]$. This is evidenced by substantial differences in the behavioral and neurobiological responses following stress exposure in mice of the same inbred strain undergoing equal husbandry and experimental conditions [80]. Environmental factors can have marked effects on dominance hierarchies.

Indeed, neuropathic pain led to a loss of dominance in formerly dominant male mice, such that the previously subordinate mouse became dominant [81]. Other negative environmental factors, such as repeated maternal separation, resulted in impaired social behaviors and induced a lower rank under group-housing conditions in adult male mice [82]. Stress is also known to affect social ranking, as mice subjected to chronic restraint stress showed a reduction in social dominance [83]. Apparently, if one of two male rats was stressed just before their first encounter, stress potentiated a hierarchy-linked recognition memory between "specific" individuals in the favor of a submissive profile for the stressed animal [84]. Under control conditions, the social rank established through a first interaction and food competition test between two male rats was not maintained when animals were confronted one week later [84]. Likewise, peripheral [85] or intracerebroventricular glucocorticoid injection [86] to emerging subordinate rats facilitated the long-term establishment of subordinate rank. Such negative environmental factors diminish the dominant rank or maintain the submissive behavior once a hierarchical relationship is established.

Conversely, when monkeys' social ranks were manipulated by placing them into new social groups, previously subordinate monkeys showed significant increases in $D_{2 / 3}$ receptor availability in the striatum, with the largest increase observed in those that became dominant after reorganization [49]. In parallel, cocaine potency as a reinforcer decreased in the majority of animals [49]. These results indicate that the transition to a dominant rank can result in neurobiological adaptations in the brain DA system that have been associated with a decreased sensitivity to cocaine reinforcement in male monkeys.

\section{Is It Possible to Shift from Down to Top?}

As mentioned previously, exposure to a negative environment incites dropping from a top to a down rank, thereby increasing the vulnerability to cocaine abuse-related effects.

One important question is whether it is possible to shift a subordinate or low-ranked profile to a dominant, high-ranked one. Interestingly, a dorsomedial PFC neural population activation was sufficient to quickly induce dominance behavior in the tube test [87]. In line with studies pointing out a role of glucocorticoids in maintaining established subordinate rank, a selective mutation in mouse glucocorticoid receptor genes in DA-innervated neurons including NAc GABAergic neurons, resulted in a higher social ranking as measured by a significantly higher probability to win in a tube test [21], in decreased motivation to self-administer cocaine, and in a lower VTA DA cell firing [88]. Moreover, a permanent, but not a transient reduction in the activity of VTA DA neurons during dominance assessment in the tube test increased the probability of the individual reaching the highest rank [21], thus suggesting that VTA DA neurons activity reduction is in the favor of top rank establishment [21]. 
As $\mathrm{D}_{2 / 3}$ receptor binding was elevated in the NAc shell of dominant rats when compared to subordinate rats, and was accompanied by reduced DA levels [14], the question that arises is whether an inhibition of the activation of VTA DA neurons projecting to the NAc shell specifically would be able to switch from a subordinate to a dominant rank and/or whether an overexpression of DA $D_{2}$ receptors in the NAc shell would be sufficient to promote a high rank profile (Figure 2). Manipulations of the VTA to NAc shell projections would uncover the cause of higher $\mathrm{D}_{2 / 3}$ receptor binding observed in dominant animals. Indeed, it is not clear whether higher $\mathrm{D}_{2}$ receptor availability is a result of increased $\mathrm{D}_{2}$ receptor density or reduced DA release from VTA to NAc neurons $[6,53,89,90]$. The next question is to determine the subsequent impact of the down-to-top switch on the effects of drugs. Indeed, there is a gap in our understanding of the effects of social ranking, identified based on non-aggressive selections, on the reinstatement of cocaine seeking, particularly stress-induced reinstatement of cocaine seeking [91,92]. This knowledge would help to elucidate why dominant individuals are more resilient to cocaine relapse provoked by stressful stimuli than submissive individuals are.

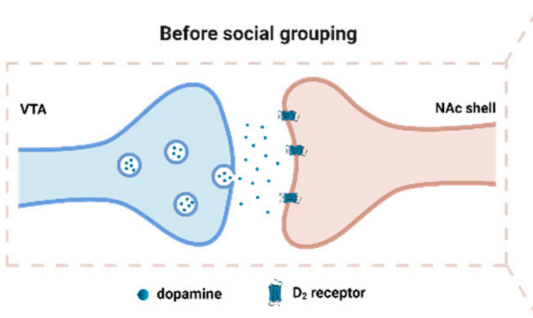

- dopamine $\mathrm{D}_{2}$ receptor
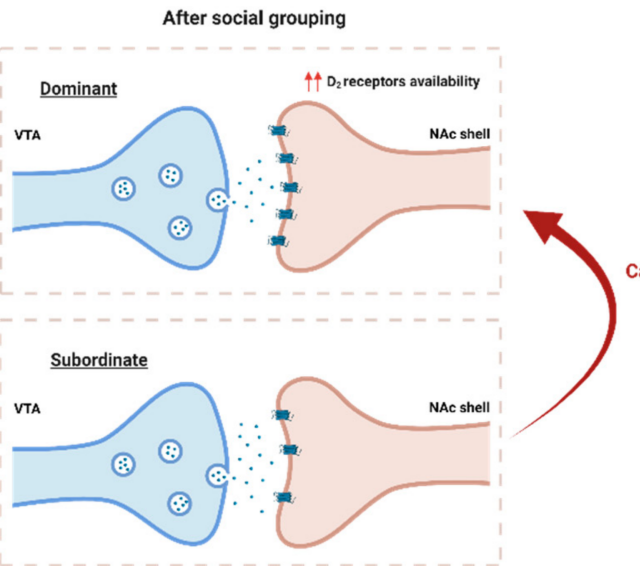

an overexpression of $D_{2}$ receptors in the NAc shel

or inhibition of VTA-NAC shell DA projections

shift from down to top rank?

Effect on reinstatement to drugs of abuse?

Figure 2. Effect of social grouping on VTA to NAc shell dopaminergic signaling. After social grouping, dominant individuals exhibited higher $D_{2 / 3}$ receptor availability in the NAc shell [14]. However, $D_{2 / 3}$ receptor availability was unchanged in subordinates [13]. Higher $D_{2 / 3}$ receptor binding observed in dominant animals might be due to higher $D_{2 / 3}$ receptor levels or reduced DA release. Can overexpression of $\mathrm{D}_{2}$ receptors in the NAc shell or inhibition of VTA-NAc shell projections shift a subordinate susceptible profile to a dominant resilient profile? What is the subsequent effect of this shift on reinstatement to drugs of abuse? Tackling this question would uncover the cause of higher D2/3 receptor binding observed in dominant animals. VTA, ventral tegmental area; NAc shell, nucleus accumbens shell.

The last remaining question is what happens to these VTA to NAc shell projections in the case of social reorganization [49], or in case the social rank in a group changes (Figure 3). A previous study found a substantial increase in $\mathrm{D}_{2 / 3}$ receptor availability in the caudate and putamen nucleus in monkeys who had been subordinate but became dominant when placed in their new social groups [49]. Such a social reorganization in male monkeys was compared to a switch in a relative enriched environmental condition resulting in adaptations in the brain DA systems [49]. Simply changing the social environment appears to be enough to increase $\mathrm{D}_{2 / 3}$ receptor availability, as evidenced by a moderate increase in the caudate nucleus of subordinate monkeys that did not increase their rank in the new social groups [49], thereby supporting the contribution of an environmental alteration to a successful therapeutic approach to cocaine addiction [49]. However, the change in environmental factors should provide the possibility for improvement (rank shift from subordinate to dominant or rank stability as subordinates in a new environment), as depriving mice from an enriched environment was perceived as a stressful and aversive experience that increased vulnerability to cocaine [93]. 

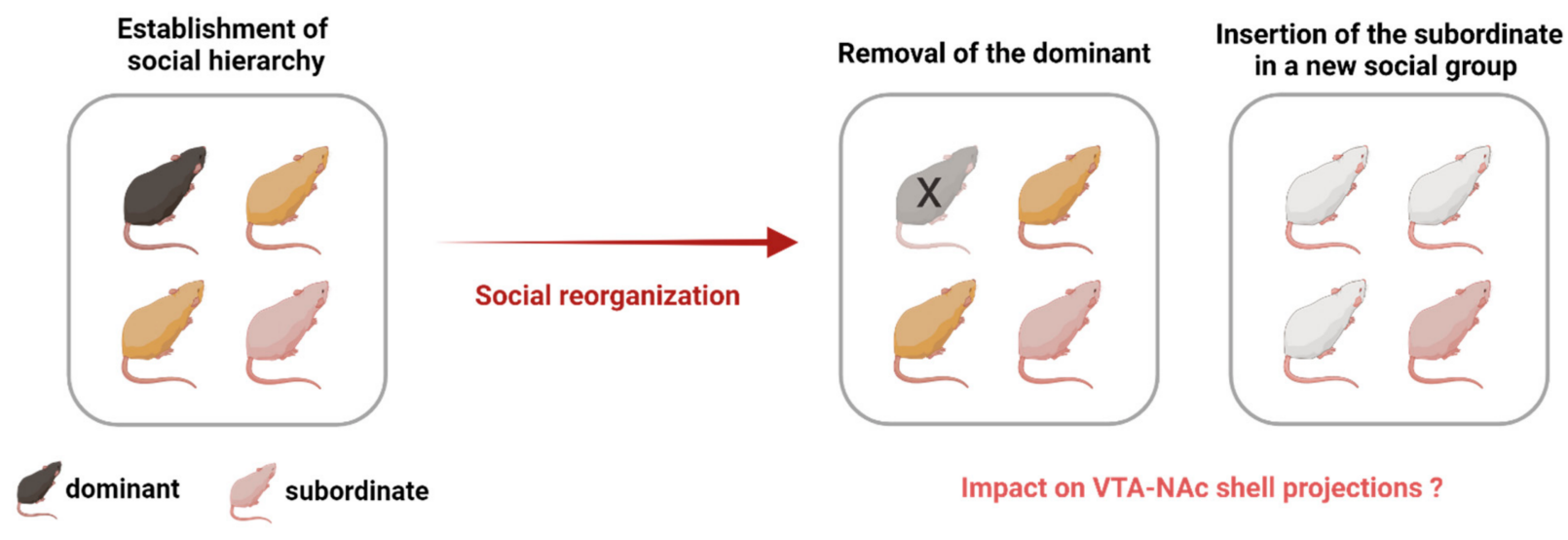

Impact on VTA-NAC shell projections ?

Figure 3. Social reorganization after the establishment of social hierarchy. Social ranks can be manipulated by removing the dominant so that a new dominance can be established, or social reorganization can occur by placing the subordinate into a new social group. What is the impact of social rank reorganization on the mesolimbic system, particularly on the VTA-NAc shell projections? In addition, what is the subsequent impact on the effects of drugs of abuse? Answering these questions will elucidate whether attaining dominance or moving to a new social group can result in adaptations in the VTA-NAc shell projections, possibly affecting the response to drugs of abuse.

The modulation of the mesolimbic system can also occur via manipulations of the systems interacting with the mesolimbic DA pathway. A possible candidate is the serotonergic (5-HT) system. The 5-HT system can influence the abuse-related effects of cocaine through its interactions with the DA system [94]. The raphe nuclei, containing the serotonergic cell bodies, projects to key brain areas involved in drug abuse, including the VTA, the NAc and the PFC. Administration of serotonin transporter inhibitors that enhance 5-HT levels can reduce the firing and burst rate of DA cells in the VTA and negatively modulate the abuse-related effects of cocaine [94], consistent with a dominant profile. Several studies have shown that this 5-HT system contributes to the formation of social hierarchy [95]. Indeed, dominant male adult vervet monkeys have approximately twice as high wholeblood serotonin concentration compared to subordinate adult males [96]. Interestingly, the shift from the down to the top position in the social hierarchy was accompanied by an increase in 5-HT levels [95]. After removing the dominant monkey of the group, the administration of drugs that enhance serotonergic activity promoted the acquisition of a dominant profile [97]. However, the administration of drugs that reduce serotonergic function promoted a subordinate profile [97]. Thus, through the manipulation of the 5-HT system, the mesolimbic DA can be modulated and can affect the social rank of the individuals, as well as the abuse-related effects of cocaine.

\section{Conclusions}

Socioeconomic status impacts human health and susceptibility to develop psychiatric disorders such as substance use disorders $[98,99]$. The social environment has a powerful influence on how individuals experience and cope with negative encounters. Regardless of whether this negative encounter was an adverse environmental condition or an exposure to drugs of abuse, social behavior and social rank in particular, are important contributors to individual differences [100] and to the individual responses to environmental challenges [101]. However, for most of the studies, social behavior and rank have been identified on the basis of a detailed observation of pairs. However, it is necessary to study animals in larger groups, rather than in pairs, and also to track individual differences within the group rather than looking at the group as a whole [102]. Indeed, only a minority (around $15 \%$ ) of rats may continue to take cocaine, while the large majority may be resilient and readily give up cocaine use in favor of a non-drug alternative [103].

Identifying the neurobiology of a potential rank switch to a resilient phenotype is of particular interest to promote a positive coping behavior toward long-term abstinence from 
drugs of abuse and a protection against relapse to drugs. Such a switch may contribute to a more successful therapeutic approach to cocaine addiction.

Author Contributions: Writing—original draft preparation, R.E.R. and I.M.A.; writing-review and editing, A.H.; funding acquisition, R.E.R. All authors have read and agreed to the published version of the manuscript.

Funding: Open Access Funding by the Austrian Science Fund (FWF), grant number T758-BBL and The APC will be funded by the FWF.

Institutional Review Board Statement: Animal experiments in this study were approved by the Austrian National Animal Experiment Ethics Committee, permit numbers BMWF-66.011/0131WF/V/3b/2016 and BMWF-66.011/0040-WF/V/3b/2019.

Informed Consent Statement: Not applicable.

Data Availability Statement: The data presented in this study should be publicly available and cited in accordance with journal guidelines.

Acknowledgments: Pictures created with BioRender.com.

Conflicts of Interest: The authors declare no conflict of interest.

\section{References}

1. Zernig, G.; Pinheiro, B.S. Dyadic social interaction inhibits cocaine-conditioned place preference and the associated activation of the accumbens corridor. Behav. Pharmacol. 2015, 26, 580-594. [CrossRef] [PubMed]

2. El Rawas, R.; Klement, S.; Kummer, K.K.; Fritz, M.; DeChant, G.; Saria, A.; Zernig, G. Brain regions associated with the acquisition of conditioned place preference for cocaine vs. social interaction. Front. Behav. Neurosci. 2012, 6, 63. [CrossRef]

3. Tanner, C.J.; Jackson, A.L. Social structure emerges via the interaction between local ecology and individual behaviour. J. Anim. Ecol. 2011, 81, 260-267. [CrossRef] [PubMed]

4. Gilboa-Schechtman, E.; Shachar, I.; Helpman, L. Evolutionary Perspective on Social Anxiety. In Social Anxiety: Clinical, Developmental, and Social Perspectives, 3rd ed.; Elsevier Inc.: Amsterdam, The Netherlands, 2014; pp. 599-622. ISBN 9780123750969.

5. Šabanović, M.; Liu, H.; Mlambo, V.; Aqel, H.; Chaudhury, D. What it takes to be at the top: The interrelationship between chronic social stress and social dominance. Brain Behav. 2020, 10, e01896. [CrossRef] [PubMed]

6. Nader, M.A.; Czoty, P.W.; Nader, S.H.; Morgan, A. Nonhuman primate models of social behavior and cocaine abuse. Psychopharmacology 2012, 224, 57-67. [CrossRef]

7. Nader, M.A.; Czoty, P.W.; Gould, R.W.; Riddick, N.V. Positron emission tomography imaging studies of dopamine receptors in primate models of addiction. Philos. Trans. R. Soc. B Biol. Sci. 2008, 363, 3223-3232. [CrossRef] [PubMed]

8. Larrieu, T.; Sandi, C. Stress-Induced Depression: Is Social Rank a Predictive Risk Factor? BioEssays 2018, 40, e1800012. [CrossRef]

9. Zhou, T.; Sandi, C.; Hu, H. Advances in understanding neural mechanisms of social dominance. Curr. Opin. Neurobiol. 2018, 49, 99-107. [CrossRef]

10. Tarter, R.E.; Kirisci, L.; Kirillova, G.P.; Gavaler, J.; Giancola, P.; Vanyukov, M.M. Social dominance mediates the association of testosterone and neurobehavioral disinhibition with risk for substance use disorder. Psychol. Addict. Behav. 2007, 21, 462-468. [CrossRef]

11. Covington, H.E.; Miczek, K.A. Repeated social-defeat stress, cocaine or morphine. Psychopharmacology 2001, 158, 388-398. [CrossRef]

12. Covington, H.E.; Kikusui, T.; Goodhue, J.; Nikulina, E.M.; Hammer, R.P.; Miczek, K.A. Brief Social Defeat Stress: Long Lasting Effects on Cocaine Taking During a Binge and Zif268 mRNA Expression in the Amygdala and Prefrontal Cortex. Neuropsychopharmacology 2004, 30, 310-321. [CrossRef]

13. Morgan, D.; Grant, K.A.; Gage, H.D.; Mach, R.H.; Kaplan, J.R.; Prioleau, O.; Nader, S.H.; Buchheimer, N.; Ehrenkaufer, R.L.; Nader, M.A. Social dominance in monkeys: Dopamine D2 receptors and cocaine self-administration. Nat. Neurosci. 2002, 5, 169-174. [CrossRef] [PubMed]

14. Jupp, B.; Murray, J.; Jordan, E.R.; Xia, J.; Fluharty, E.M.; Shrestha, S.; Robbins, T.; Dalley, J.W. Social dominance in rats: Effects on cocaine self-administration, novelty reactivity and dopamine receptor binding and content in the striatum. Psychopharmacology 2016, 233, 579-589. [CrossRef]

15. EL Rawas, R.; Amaral, I.; Hofer, A. Social Interaction Reward: A Resilience Approach to Overcome Vulnerability to Drugs of Abuse. Eur. Neuropsychopharmacol. 2020, 1. [CrossRef] [PubMed]

16. Covington, H.E.; Miczek, K.A. Intense cocaine self-administration after episodic social defeat stress, but not after aggressive behavior: Dissociation from corticosterone activation. Psychopharmacology 2005, 183, 331-340. [CrossRef]

17. Tornatzky, W.; Miczek, K.A. Long-term impairment of autonomic circadian rhythms after brief intermittent social stress. Physiol. Behav. 1993, 53, 983-993. [CrossRef]

18. Hollis, F.; Kabbaj, M. Social Defeat as an Animal Model for Depression. ILAR J. 2014, 55, 221-232. [CrossRef] [PubMed] 
19. Czoty, P.W.; McCabe, C.; Nader, M.A. Assessment of the Relative Reinforcing Strength of Cocaine in Socially Housed Monkeys Using a Choice Procedure. J. Pharmacol. Exp. Ther. 2004, 312, 96-102. [CrossRef] [PubMed]

20. Fan, Z.; Zhu, H.; Zhou, T.; Wang, S.; Wu, Y.; Hu, H. Using the tube test to measure social hierarchy in mice. Nat. Protoc. 2019, 14, 819-831. [CrossRef] [PubMed]

21. Battivelli, D.; Vernochet, C.; Nguyen, C.; Bhattacharya, S.; Zayed, A.; Meirsman, A.C.; Messaoudene, S.; Fieggen, A.; Tassin, J.P.; Marti, F.; et al. Social status influences normal and pathological behaviors in mice, a role for dopamine and stress signaling. bioRxiv 2019, 856781. [CrossRef]

22. Yanovich, C.; Kirby, M.L.; Michaelevski, I.; Yadid, G.; Pinhasov, A. Social rank-associated stress vulnerability predisposes individuals to cocaine attraction. Sci. Rep. 2018, 8, 1-9. [CrossRef] [PubMed]

23. Calcagnetti, D.J.; Schechter, M.D. Place conditioning reveals the rewarding aspect of social interaction in juvenile rats. Physiol. Behav. 1992, 51, 667-672. [CrossRef]

24. Fritz, M.; El Rawas, R.; Salti, A.; Klement, S.; Bardo, M.T.; Kemmler, G.; Dechant, G.; Saria, A.; Zernig, G. Reversal of cocaineconditioned place preference and mesocorticolimbic Zif268 expression by social interaction in rats. Addict. Biol. 2011, 16, 273-284. [CrossRef] [PubMed]

25. Lemos, C.; Salti, A.; Amaral, I.M.; Fontebasso, V.; Singewald, N.; Dechant, G.; Hofer, A.; El Rawas, R. Social interaction reward in rats has anti-stress effects. Addict. Biol. 2021, 26, e12878. [CrossRef] [PubMed]

26. Amaral, I.M.; Lemos, C.; Cera, I.; DeChant, G.; Hofer, A.; El Rawas, R. Involvement of cAMP-Dependent Protein Kinase in the Nucleus Accumbens in Cocaine Versus Social Interaction Reward. Int. J. Mol. Sci. 2020, 22, 345. [CrossRef] [PubMed]

27. Fritz, M.; El Rawas, R.; Klement, S.; Kummer, K.; Mayr, M.J.; Eggart, V.; Salti, A.; Bardo, M.T.; Saria, A.; Zernig, G. Differential Effects of Accumbens Core vs. Shell Lesions in a Rat Concurrent Conditioned Place Preference Paradigm for Cocaine vs. Social Interaction. PLoS ONE 2011, 6, e26761. [CrossRef]

28. Sampedro-Piquero, P.; Ávila-Gámiz, F.; Moreno-Fernandez, R.D.; Castilla-Ortega, E.; Santín, L.J. The presence of a social stimulus reduces cocaine-seeking in a place preference conditioning paradigm. J. Psychopharmacol. 2019, 33, 1501-1511. [CrossRef]

29. Pinheiro, B.S.; Seidl, S.S.; Habazettl, E.; Gruber, B.E.; Bregolin, T.; Zernig, G. Dyadic social interaction of C57BL/6 mice versus interaction with a toy mouse. Behav. Pharmacol. 2016, 27, 279-288. [CrossRef]

30. Bregolin, T.; Pinheiro, B.S.; El Rawas, R.; Zernig, G. Preventive Strength of Dyadic Social Interaction against Reacquisition/Reexpression of Cocaine Conditioned Place Preference. Front. Behav. Neurosci. 2017, 11, 225. [CrossRef]

31. El Rawas, R.; Saria, A. The Two Faces of Social Interaction Reward in Animal Models of Drug Dependence. Neurochem. Res. 2016, 41, 492-499. [CrossRef]

32. Smith, M.A. Peer influences on drug self-administration: Social facilitation and social inhibition of cocaine intake in male rats. Psychopharmacology 2012, 224, 81-90. [CrossRef] [PubMed]

33. Dingess, P.M.; Deters, M.J.; Darling, R.A.; Yarborough, E.A.; Brown, T.E. A method for evaluating cocaine-induced social preference in rats. J. Biol. Methods 2017, 4, e66. [CrossRef]

34. Smith, M.A.; Pitts, E. Social preference and drug self-administration: A preclinical model of social choice within peer groups. Drug Alcohol Depend. 2014, 135, 140-145. [CrossRef] [PubMed]

35. Smith, M.A.; Strickland, J.; Bills, S.E.; Lacy, R.T. The effects of a shared history of drug exposure on social choice. Behav. Pharmacol. 2015, 26, 631-635. [CrossRef] [PubMed]

36. Thiel, K.J.; Okun, A.C.; Neisewander, J.L. Social reward-conditioned place preference: A model revealing an interaction between cocaine and social context rewards in rats. Drug Alcohol Depend. 2008, 96, 202-212. [CrossRef] [PubMed]

37. Thiel, K.J.; Sanabria, F.; Neisewander, J.L. Synergistic interaction between nicotine and social rewards in adolescent male rats. Psychopharmacology 2009, 204, 391-402. [CrossRef]

38. Watanabe, S. Drug-social interactions in the reinforcing property of methamphetamine in mice. Behav. Pharmacol. 2011, 22, 203-206. [CrossRef]

39. Adinoff, B. Neurobiologic Processes in Drug Reward and Addiction. Harv. Rev. Psychiatry 2004, 12, 305-320. [CrossRef]

40. Di Chiara, G.; Imperato, A. Drugs abused by humans preferentially increase synaptic dopamine concentrations in the mesolimbic system of freely moving rats. Proc. Natl. Acad. Sci. USA 1988, 85, 5274-5278. [CrossRef]

41. Chiara, G. Nucleus accumbens shell and core dopamine: Differential role in behavior and addiction. Behav. Brain Res. 2002, 137, 75-114. [CrossRef]

42. Hyman, S.E.; Malenka, R.C.; Nestler, E.J. NEURAL MECHANISMS OF ADDICTION: The Role of Reward-Related Learning and Memory. Annu. Rev. Neurosci. 2006, 29, 565-598. [CrossRef]

43. Arias-Carrión, O.; Stamelou, M.; Murillo-Rodríguez, E.; Menéndez-González, M.; Pöppel, E. Dopaminergic reward system: A short integrative review. Int. Arch. Med. 2010, 3, 24. [CrossRef]

44. Missale, C.; Nash, S.R.; Robinson, S.W.; Jaber, M.; Caron, M.G. Dopamine Receptors: From Structure to Function. Physiol. Rev. 1998, 78, 189-225. [CrossRef] [PubMed]

45. Martinez, D.; Orlowska, D.; Narendran, R.; Slifstein, M.; Liu, F.; Kumar, D.; Broft, A.; Van Heertum, R.; Kleber, H.D. Dopamine Type 2/3 Receptor Availability in the Striatum and Social Status in Human Volunteers. Biol. Psychiatry 2010, 67, $275-278$. [CrossRef] [PubMed]

46. Bowling, S.L.; Rowlett, J.K.; Bardo, M.T. The effect of environmental enrichment on amphetamine-stimulated locomotor activity, dopamine synthesis and dopamine release. Neuropharmacology 1993, 32, 885-893. [CrossRef] 
47. Solinas, M.; Thiriet, N.; El Rawas, R.; Lardeux, V.; Jaber, M. Environmental Enrichment During Early Stages of Life Reduces the Behavioral, Neurochemical, and Molecular Effects of Cocaine. Neuropsychopharmacology 2008, 34, 1102-1111. [CrossRef]

48. El Rawas, R.; Thiriet, N.; Lardeux, V.; Jaber, M.; Solinas, M. Environmental enrichment decreases the rewarding but not the activating effects of heroin. Psychopharmacology 2009, 203, 561-570. [CrossRef]

49. Czoty, P.W.; Gould, R.W.; Gage, H.D.; Nader, M.A. Effects of social reorganization on dopamine D2/D3 receptor availability and cocaine self-administration in male cynomolgus monkeys. Psychopharmacology 2017, 234, 2673-2682. [CrossRef] [PubMed]

50. Rosenzweig, M.R.; Bennett, E.L. Psychobiology of plasticity: Effects of training and experience on brain and behavior. Behav. Brain Res. 1996, 78, 57-65. [CrossRef]

51. Solinas, M.; Thiriet, N.; Chauvet, C.; Jaber, M. Prevention and treatment of drug addiction by environmental enrichment. Prog. Neurobiol. 2010, 92, 572-592. [CrossRef]

52. Laviola, G.; Hannan, A.; Macrì, S.; Solinas, M.; Jaber, M. Effects of enriched environment on animal models of neurodegenerative diseases and psychiatric disorders. Neurobiol. Dis. 2008, 31, 159-168. [CrossRef]

53. Nader, M.A.; Nader, S.H.; Czoty, P.W.; Riddick, N.V.; Gage, H.D.; Gould, R.W.; Blaylock, B.L.; Kaplan, J.R.; Garg, P.K.; Davies, H.M.; et al. Social Dominance in Female Monkeys: Dopamine Receptor Function and Cocaine Reinforcement. Biol. Psychiatry 2012, 72, 414-421. [CrossRef]

54. Bezard, E.; Dovero, S.; Belin, D.; Duconger, S.; Jackson-Lewis, V.; Przedborski, S.; Piazza, P.V.; Gross, C.E.; Jaber, M. Enriched Environment Confers Resistance to 1-Methyl-4-Phenyl-1,2,3,6-Tetrahydropyridine and Cocaine: Involvement of Dopamine Transporter and Trophic Factors. J. Neurosci. 2003, 23, 10999-11007. [CrossRef]

55. Grant, K.A.; Shively, C.A.; Nader, M.A.; Ehrenkaufer, R.L.; Line, S.W.; Morton, T.E.; Donald Gage, H.; Mach, R.H. Effect of social status on striatal dopamine D2 receptor binding characteristics in cynomolgus monkeys assessed with positron emission tomography. Synapse 1998, 29, 80-83. [CrossRef]

56. Giros, B.; Jaber, M.; Jones, S.; Wightman, R.M.; Caron, M.G. Hyperlocomotion and indifference to cocaine and amphetamine in mice lacking the dopamine transporter. Nat. Cell Biol. 1996, 379, 606-612. [CrossRef] [PubMed]

57. Rocha, B.A.; Fumagalli, F.; Gainetdinov, R.; Jones, S.R.; Ator, R.; Giros, B.; Miller, G.W.; Caron, M.G. Cocaine self-administration in dopamine-transporter knockout mice. Nat. Neurosci. 1998, 1, 132-137. [CrossRef] [PubMed]

58. Caine, S.B.; Negus, S.S.; Mello, N.K.; Patel, S.; Bristow, L.; Kulagowski, J.; Vallone, D.; Saiardi, A.; Borrelli, E. Role of Dopamine D2-like Receptors in Cocaine Self-Administration: Studies with D2 Receptor Mutant Mice and Novel D2 Receptor Antagonists. J. Neurosci. 2002, 22, 2977-2988. [CrossRef]

59. Song, R.; Zhang, H.; Li, X.; Bi, G.-H.; Gardner, E.L.; Xi, Z.-X. Increased vulnerability to cocaine in mice lacking dopamine D3 receptors. Proc. Natl. Acad. Sci. USA 2012, 109, 17675-17680. [CrossRef]

60. Dalley, J.W.; Fryer, T.D.; Brichard, L.; Robinson, E.; Theobald, D.E.H.; Lääne, K.; Peña, Y.; Murphy, E.R.; Shah, Y.; Probst, K.; et al. Nucleus Accumbens D2/3 Receptors Predict Trait Impulsivity and Cocaine Reinforcement. Science 2007, 315, 1267-1270. [CrossRef] [PubMed]

61. Bellés, L.; Dimiziani, A.; Tsartsalis, S.; Millet, P.; Herrmann, F.R.; Ginovart, N. Dopamine D2/3 Receptor Availabilities and Evoked Dopamine Release in Striatum Differentially Predict Impulsivity and Novelty Preference in Roman High- and Low-Avoidance Rats. Int. J. Neuropsychopharmacol. 2021, 24, 239-251. [CrossRef]

62. London, E.D. Human Brain Imaging Links Dopaminergic Systems to Impulsivity. In Current Topics in Behavioral Neurosciences; Springer Science and Business Media Deutschland GmbH: Berlin/Heidelberg, Germany, 2020; Volume 47, pp. 53-71.

63. Moreno, M.; Azocar, V.; Vergés, A.; Fuentealba, J.A. High impulsive choice is accompanied by an increase in dopamine release in rat dorsolateral striatum. Behav. Brain Res. 2021, 405, 113199. [CrossRef]

64. Adriani, W.; Boyer, F.; Gioiosa, L.; Macrì, S.; Dreyer, J.-L.; Laviola, G. Increased impulsive behavior and risk proneness following lentivirus-mediated dopamine transporter over-expression in rats' nucleus accumbens. Neuroscience 2009, 159, 47-58. [CrossRef]

65. Riddick, N.V.; Czoty, P.W.; Gage, H.D.; Kaplan, J.R.; Nader, S.H.; Icenhower, M.; Pierre, P.J.; Bennett, A.; Garg, P.K.; Garg, S.; et al. Behavioral and neurobiological characteristics influencing social hierarchy formation in female cynomolgus monkeys. Neuroscience 2009, 158, 1257-1265. [CrossRef] [PubMed]

66. Czoty, P.W.; Gage, H.D.; Nader, M.A. Differences in D2 dopamine receptor availability and reaction to novelty in socially housed male monkeys during abstinence from cocaine. Psychopharmacology 2010, 208, 585-592. [CrossRef] [PubMed]

67. Dalley, J.; Everitt, B.; Robbins, T. Impulsivity, Compulsivity, and Top-Down Cognitive Control. Neuron 2011, 69, 680-694. [CrossRef]

68. Yamaguchi, Y.; Lee, Y.-A.; Kato, A.; Jas, E.; Goto, Y. The Roles of Dopamine D2 Receptor in the Social Hierarchy of Rodents and Primates. Sci. Rep. 2017, 7, 43348. [CrossRef]

69. Torquet, N.; Marti, F.; Campart, C.; Tolu, S.; Nguyen, C.; Oberto, V.; Benallaoua, M.; Naudé, J.; Didienne, S.; Debray, N.; et al. Social interactions impact on the dopaminergic system and drive individuality. Nat. Commun. 2018, 9, 3081. [CrossRef]

70. Volkow, N.D.; Wang, G.-J.; Fowler, J.S.; Thanos, P.; Logan, J.; Gatley, S.J.; Gifford, A.; Ding, Y.-S.; Wong, C.; Pappas, N. Brain DA D2 receptors predict reinforcing effects of stimulants in humans: Replication study. Synapse 2002, 46, 79-82. [CrossRef]

71. Gjedde, A.; Kumakura, Y.; Cumming, P.; Linnet, J.; Møller, A. Inverted-U-shaped correlation between dopamine receptor availability in striatum and sensation seeking. Proc. Natl. Acad. Sci. USA 2010, 107, 3870-3875. [CrossRef] [PubMed] 
72. Van Der Kooij, M.A.; Hollis, F.; Lozano, L.; Zalachoras, I.; Abad, S.; Zanoletti, O.; Grosse, J.; De Suduiraut, I.G.; Canto, C.; Sandi, C. Diazepam actions in the VTA enhance social dominance and mitochondrial function in the nucleus accumbens by activation of dopamine D1 receptors. Mol. Psychiatry 2017, 23, 569-578. [CrossRef]

73. Lozano-Montes, L.; Astori, S.; Abad, S.; De Suduiraut, I.G.; Sandi, C.; Zalachoras, I. Latency to Reward Predicts Social Dominance in Rats: A Causal Role for the Dopaminergic Mesolimbic System. Front. Behav. Neurosci. 2019, 13, 69. [CrossRef]

74. Plavén-Sigray, P.; Gustavsson, P.; Farde, L.; Borg, J.; Stenkrona, P.; Nyberg, L.; Bäckman, L.; Cervenka, S. Dopamine D1 receptor availability is related to social behavior: A positron emission tomography study. NeuroImage 2014, 102, 590-595. [CrossRef]

75. Couppis, M.H.; Kennedy, C.H.; Stanwood, G.D. Differences in aggressive behavior and in the mesocorticolimbic DA system between A/J and BALB/cJ mice. Synapse 2008, 62, 715-724. [CrossRef] [PubMed]

76. Yamaguchi, Y.; Lee, Y.-A.; Kato, A.; Goto, Y. The Roles of Dopamine D1 Receptor on the Social Hierarchy of Rodents and Non-human Primates. Int. J. Neuropsychopharmacol. 2016, 20, 324-335. [CrossRef]

77. Hollis, F.; van der Kooij, M.; Zanoletti, O.; Lozano, L.; Cantó, C.; Sandi, C. Mitochondrial function in the brain links anxiety with social subordination. Proc. Natl. Acad. Sci. USA 2015, 112, 15486-15491. [CrossRef]

78. Larrieu, T.; Cherix, A.; Duque, A.; Rodrigues, J.; Lei, H.; Gruetter, R.; Sandi, C. Hierarchical Status Predicts Behavioral Vulnerability and Nucleus Accumbens Metabolic Profile Following Chronic Social Defeat Stress. Curr. Biol. 2017, 27, 2202-2210. [CrossRef]

79. Kunkel, T.; Wang, H. Socially dominant mice in C57BL6 background show increased social motivation. Behav. Brain Res. 2018, 336, 173-176. [CrossRef] [PubMed]

80. Krishnan, V.; Han, M.-H.; Graham, D.L.; Berton, O.; Renthal, W.; Russo, S.; LaPlant, Q.; Graham, A.; Lutter, M.; Lagace, D.C.; et al. Molecular Adaptations Underlying Susceptibility and Resistance to Social Defeat in Brain Reward Regions. Cell 2007, 131, 391-404. [CrossRef]

81. Tansley, S.N.; Tuttle, A.H.; Wu, N.; Tohyama, S.; Dossett, K.; Gerstein, L.; Ham, B.; Austin, J.-S.; Sotocinal, S.G.; Mogil, J.S. Modulation of social behavior and dominance status by chronic pain in mice. Genes Brain Behav. 2018, 18, e12514. [CrossRef] [PubMed]

82. Endo, N.; Makinodan, M.; Mannari-Sasagawa, T.; Horii-Hayashi, N.; Somayama, N.; Komori, T.; Kishimoto, T.; Nishi, M. The effects of maternal separation on behaviours under social-housing environments in adult male C57BL/6 mice. Sci. Rep. 2021, 11, 1-11. [CrossRef] [PubMed]

83. Park, M.-J.; Seo, B.A.; Lee, B.; Shin, H.-S.; Kang, M.-G. Stress-induced changes in social dominance are scaled by AMPA-type glutamate receptor phosphorylation in the medial prefrontal cortex. Sci. Rep. 2018, 8, 15008. [CrossRef]

84. Isabel, M.; Cordero, M.I.; Sandi, C. Stress amplifies memory for social hierarchy. Front. Behav. Neurosci. 2007, 1, 175-184. [CrossRef] [PubMed]

85. Timmer, M.; Sandi, C. A role for glucocorticoids in the long-term establishment of a social hierarchy. Psychoneuroendocrinology 2010, 35, 1543-1552. [CrossRef] [PubMed]

86. Weger, M.; Sevelinges, Y.; Grosse, J.; de Suduiraut, I.G.; Zanoletti, O.; Sandi, C. Increased brain glucocorticoid actions following social defeat in rats facilitates the long-term establishment of social subordination. Physiol. Behav. 2018, 186, 31-36. [CrossRef] [PubMed]

87. Zhou, T.; Zhu, H.; Fan, Z.; Wang, F.; Chen, Y.; Liang, H.; Yang, Z.; Zhang, L.; Lin, L.; Zhan, Y.; et al. History of winning remodels thalamo-PFC circuit to reinforce social dominance. Science 2017, 357, 162-168. [CrossRef]

88. Ambroggi, F.; Turiault, M.; Milet, A.; Deroche-Gamonet, V.; Parnaudeau, S.; Balado, E.; Barik, J.; Van Der Veen, R.; Maroteaux, G.; Lemberger, T.; et al. Stress and addiction: Glucocorticoid receptor in dopaminoceptive neurons facilitates cocaine seeking. Nat. Neurosci. 2009, 12, 247-249. [CrossRef] [PubMed]

89. Červenka, S.; Gustavsson, J.P.; Halldin, C.; Farde, L. Association between striatal and extrastriatal dopamine D2-receptor binding and social desirability. NeuroImage 2010, 50, 323-328. [CrossRef]

90. Bello, E.P.; Mateo, Y.; Gelman, D.M.; Noaín, D.; Shin, J.H.; Low, M.J.; Alvarez, V.; Lovinger, D.M.; Rubinstein, M. Cocaine supersensitivity and enhanced motivation for reward in mice lacking dopamine D2 autoreceptors. Nat. Neurosci. 2011, 14, 1033-1038. [CrossRef]

91. Mantsch, J.R.; Baker, D.; Funk, D.; Lê, A.D.; Shaham, Y. Stress-Induced Reinstatement of Drug Seeking: 20 Years of Progress. Neuropsychopharmacology 2016, 41, 335-356. [CrossRef]

92. Sinha, R. How does stress increase risk of drug abuse and relapse? Psychopharmacology 2001, 158, 343-359. [CrossRef]

93. Nader, J.; Claudia, C.; El Rawas, R.; Favot, L.; Jaber, M.; Thiriet, N.; Solinas, M. Loss of Environmental Enrichment Increases Vulnerability to Cocaine Addiction. Neuropsychopharmacology 2012, 37, 1579-1587. [CrossRef] [PubMed]

94. Howell, L.L.; Cunningham, K.A. Serotonin 5-HT2 Receptor Interactions with Dopamine Function: Implications for Therapeutics in Cocaine Use Disorder. Pharmacol. Rev. 2015, 67, 176-197. [CrossRef]

95. Ewatanabe, N.; Eyamamoto, M. Neural mechanisms of social dominance. Front. Neurosci. 2015, 9, 154. [CrossRef] [PubMed]

96. Raleigh, M.J. Social and Environmental Influences on Blood Serotonin Concentrations in Monkeys. Arch. Gen. Psychiatry 1984, 41, 405-410. [CrossRef] [PubMed]

97. Raleigh, M.J.; McGuire, M.T.; Brammer, G.L.; Pollack, D.B.; Yuwiler, A. Serotonergic mechanisms promote dominance acquisition in adult male vervet monkeys. Brain Res. 1991, 559, 181-190. [CrossRef]

98. Sapolsky, R.M. The Influence of Social Hierarchy on Primate Health. Science 2005, 308, 648-652. [CrossRef] [PubMed] 
99. Kivimäki, M.; Batty, G.D.; Pentti, J.; Shipley, M.J.; Sipilä, P.; Nyberg, S.T.; Suominen, S.B.; Oksanen, T.; Stenholm, S.; Virtanen, M.; et al. Association between socioeconomic status and the development of mental and physical health conditions in adulthood: A multi-cohort study. Lancet Public Health 2020, 5, e140-e149. [CrossRef]

100. Forkosh, O.; Karamihalev, S.; Roeh, S.; Alon, U.; Anpilov, S.; Touma, C.; Nussbaumer, M.; Flachskamm, C.; Kaplick, P.M.; Shemesh, Y.; et al. Identity domains capture individual differences from across the behavioral repertoire. Nat. Neurosci. 2019, 22, 2023-2028. [CrossRef] [PubMed]

101. Karamihalev, S.; Brivio, E.; Flachskamm, C.; Stoffel, R.; Schmidt, M.V.; Chen, A. Social dominance mediates behavioral adaptation to chronic stress in a sex-specific manner. eLife 2020, 9, 1-18. [CrossRef]

102. Shemesh, Y.; Sztainberg, Y.; Forkosh, O.; Shlapobersky, T.; Chen, A.; Schneidman, E. High-order social interactions in groups of mice. eLife 2013, 2, e00759. [CrossRef]

103. Cantin, L.; Lenoir, M.; Augier, E.; Vanhille, N.; Dubreucq, S.; Serre, F.; Vouillac, C.; Ahmed, S.H. Cocaine Is Low on the Value Ladder of Rats: Possible Evidence for Resilience to Addiction. PLoS ONE 2010, 5, e11592. [CrossRef] [PubMed] 